\title{
ВПЛИВ ТИСКУ НА КОРЕКТНІСТЬ ТЕПЛОВІЗІЙНОГО ОБСТЕЖЕННЯ
}

\section{THE INFLUENCE OF PRESSURE ON THE ACCURACY OF THERMAL IMAGING EXAMINATION}

\author{
Пахолюк О.А., к.т.н., доц., Чапюк О.С., к.т.Н., доц., Дмитрук О.В., \\ магістр (Луцький національний технічний університет, м. Луцьк)
}

\begin{abstract}
Pakholiuk O.A., Ph.D. in Engineering, Associate Professor, Chapiuk O.S., Ph.D. in Engineering, Associate Professor, Dmytruk O.V., Master (Lutsk National Technical University, Lutsk).
\end{abstract}

Анотація. Обгрунтовано необхідність проведення тепловізійного обстеження будівель, наведено типи дефектів, які можна виявити при такому обстеженні, та умови, за яких проведене обстеження дозволить виявити всі дефекти. Описано вплив на якість дослідження перепадів тиску назовні та всередині будівлі, обладнання, яке даний перепад забезпечує.

Summary. Thermal imaging examination in Ukraine is performed in accordance with DSTU B EN 13187: 2011 "Thermal characteristics of buildings. Qualitative detection of thermal failures in enclosing structures. Infrared method. It is completely identical to the European standard EN 13187: 1998.

This standard is used to identify the locations of heat failure sites and the location of air filtration areas through enclosure structures.

When conducting surveys, it is necessary to monitor and record information regarding outside air temperature, cloud cover, rainfall and humidity outside the building, along with wind parameters. The orientation of the building to the sides of the world should also be recorded.

To determine the anomaly of the thermal insulation properties of the observed deviations on the obtained thermograms, they are compared with the expected temperature distribution over the surface, determined by the design characteristics of the enclosure structure in the environmental conditions observed during the survey. The expected temperature distribution can be determined using "reference" thermograms, calculations or other studies.

If air filtration can affect the test results, a pressure difference on either side of the enclosure should be created, or the test should be performed under conditions where a pressure difference exists. If the primary purpose of the thermal imaging examination is to determine the air filtration, then the pressure difference must be not less than $5 \mathrm{~Pa}$ at the test site. Thermal imaging is performed with less pressure.

When defining air filtration locations, the operator is faced with uncertainty in the distribution of the pressure difference between the inner and outer parts of the structure. Such uncertainty arises from the influence of the following factors: temperature 
difference between indoor and outdoor air; building height; effect of wind on the structure; influence of mechanical ventilation.

A qualitative result can be obtained if, during the shooting, the wind is directed directly to the investigated part of the facade, or if excess pressure or dilution in comparison with the ambient pressure is created in the house. This can be implemented with the help of special equipment for determining the breathability of buildings, called the Blower Door Test.

Ключові слова: тепловізійне обстеження, дефект, тест на повітропроникність .

Keywords: thermal imaging examination, defect, Blower Door Test.

Неоднаковість теплових властивостей елементів зовнішніх огороджувальних конструкцій будівлі призводить до зміни температури на поверхні конструкції. На температуру поверхні також впливає потік повітря в будівлі та/або крізь огорожу будівлі. За характером розподілу температури поверхні можна виявляти теплові відмови внаслідок, наприклад, дефектів ізоляції, вмісту вологи та/або фільтрації повітря в елементах зовнішніх огороджувальних конструкцій будинку.

Термографія будівлі - метод, що відображає та представляє температурний розподіл на ділянці поверхні зовнішньої огороджувальної конструкції будинку [1]. Термографія будівель здійснюється за допомогою тепловізорів.

Тепловізійне обстеження в Україні виконується згідно з ДСТУ Б ЕN 13187:2011 «Теплові характеристики будівель. Якісне виявлення теплових відмов в огороджувальних конструкціях. Інфрачервоний метод». Він повністю ідентичний європейському стандарту EN 13187:1998.

Цей стандарт застосовують для виявлення місць розташування ділянок із тепловими відмовами та розташування ділянок фільтрації повітря крізь огороджувальні конструкції.

При проведенні обстежень необхідно контролювати та проводити фіксацію інформації, що стосується температури зовнішнього повітря, хмарності, кількості опадів та вологості з зовнішнього боку будівлі, разом із параметрами вітру. Також слід фіксувати орієнтацію будівлі за сторонами світу.

Тепловізійне обстеження ділянок будинків передбачає:

- визначення розподілу температури по поверхні ділянки огороджувальної конструкції будинку за розподілом дійсної радіаційної температури, яка отримана за допомогою системи для сприйняття інфрачервоного випромінювання;

- визначення, чи розподіл температури поверхні $є$ аномальним, тобто спричиненим, наприклад, дефектами ізоляції, вмістом вологи та/або фільтрації повітря; 
необхідно визначити тип та ступінь дефектів.

Для визначення аномальності теплоізоляційних властивостей за поміченими відхилами на отриманих термограмах їх порівнюють 3 очікуваним розподілом температури по поверхні, визначеним за запроектованими характеристиками огороджувальної конструкції в умовах навколишнього середовища, що спостерігалися під час проведення обстеження. Очікуваний розподіл температури може бути визначений за допомогою «еталонних» термограм, розрахунків або інших досліджень [1]. Визначення можна провести за допомогою креслень та інших документів, які характеризують зовнішні огороджувальні конструкції та системи опалення і вентиляції будинку, який обстежується.

У випадку, якщо фільтрація повітря може впливати на результати обстеження, потрібно створювати різницю тиску по обидва боки огороджувальної конструкції, або обстеження проводити в умовах, коли існує різниця тисків. Якщо головною метою тепловізійного обстеження $є$ визначення фільтрації повітря, тоді різниця тисків повинна бути не меншою, ніж 5 Па на місці перевірки. Тепловізійне обстеження виконують з боку меншого тиску.

При обстеженні необхідно визначати вплив вентильованих повітряних прошарків, наприклад, у стінах або джерел теплоти (при наявності), встановлених у будівлю (вбудовані труби, димоходи тощо), які впливають на температуру обстежуваних конструкцій. Джерела теплоти, що впливають на результати обстеження, повинні бути відключені до початку обстеження. Меблі, картини та інші предмети, що можуть впливати на результат, повинні бути усунені, для звільнення обстежуваних ділянок.

Безпосередньо перед початком обстеження потрібно визначити температуру внутрішнього та зовнішнього повітря 3 абсолютною похибкою \pm 1 К. Коли різниця тисків 3 обох боків конструкції підлягає визначенню, рекомендується виміряти ії з похибкою \pm 2 Па з підвітряного та навітряного боків кожного поверху. Розглянуті значення мають бути занотовані. Особливо важливо визначити напрям різниці тисків крізь ділянку будівельної конструкції і розташування нейтральної площини, якщо така $\epsilon$.

За допомогою тепловізійного обстеження зазвичай виявляють три види дефектів:

- температурні (теплові);

- вологісні;

- фільтраційні.

Перші два типи дефектів при визначенні вимагають відповідного температурного напору, який, як правило, повинен складати не менше 15 
градусів. Третій тип вимагає наявності сталого перепаду тиску, який далеко не завжди присутній, особливо у міжсезоння.

При визначенні місць фільтрації повітря оператор стикається 3 невизначеністю розподілу різниці тиску між внутрішньою і зовнішньою частинами будівельної конструкції. Така невизначеність виникає при впливі таких факторів:

- різниця температур внутрішнього і зовнішнього повітря;

- висота будівлі;

- вплив вітру на конструкцію;

- вплив механічної вентиляції.

Наведені вище чинники і їх взаємодія можуть впливати на напрям потоків фільтрації або призводити до їх відсутності. Тому дефект може бути не виявлений, якщо вектор перепаду тиску повітря, тобто повітряний потік у момент зйомки спрямований від оператора.

Якісний результат можна отримати, якщо під час зйомки вітер спрямований саме на досліджувану частину фасаду або якщо в будинку створено надлишковий тиск або розрідження у порівнянні 3 тиском навколишнього середовища. Це може бути реалізовано за допомогою спеціального обладнання для визначення повітропроникності будівель, яке носить назву Blower Door Test (аеродвері).

До складу даного обладнання входять:

- розсувна металева рамка;

- повітронепроникна тканина;

- калібрований вентилятор;

- диференційний манометр

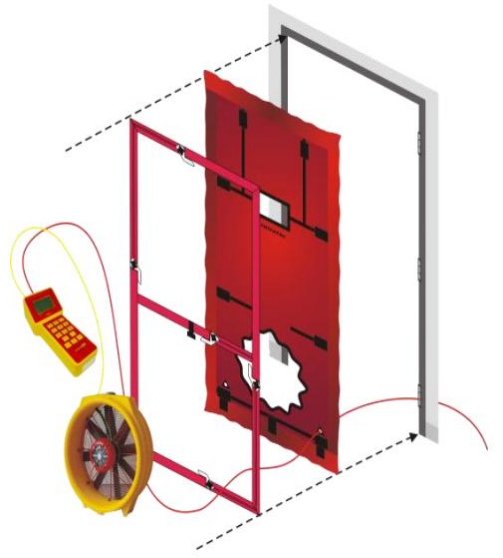

Рис. 1. Схема аеродверей

Слід зазначити, що дана система може бути як одно-, так i багатовентиляторною. 


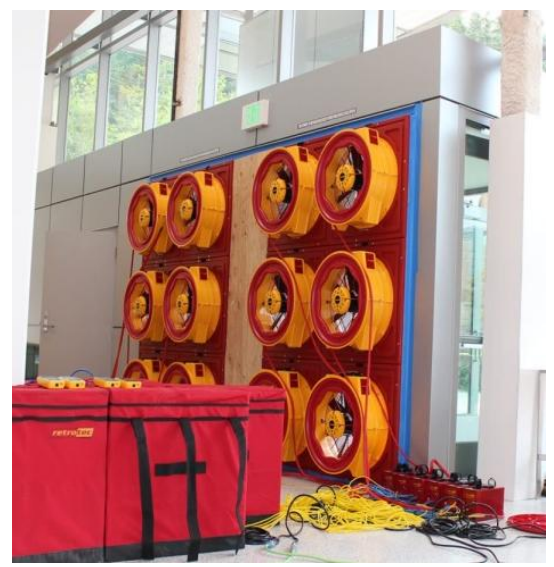

Рис. 2. Багатовентиляторна установка для перевірки будівель на повітропроникність

Тепловізійне обстеження, проведене при гарантованому перепаді тиску, дозволяє:

- виключити вплив чинників, що знижують ймовірність визначення дефекту (наприклад, вітер, ефект димової труби тощо);

- визначати місця фільтрації при малих різницях температур (наприклад, влітку або на об'єктах, де ця різниця незначна);

- знаходити місця фільтрації при проведенні вимірювання повітропроникності огороджувальної конструкції.

Чинна редакція ДБН В 2.6-31-2016 «Теплова ізоляція будівель» визначає, що необхідною умовою проектування при новому будівництві, реконструкції, капітальному ремонті, термомодернізації $\epsilon$ досягнення класу енергетичної ефективності не нижче, ніж клас «С». Однією 3 обов'язкових умов досягнення цього класу $\epsilon$ відповідність огороджувальних конструкцій нормам повітропроникності, які визначені у ДСТУ-Н Б В.2.6-191 2013. «Настанова 3 розрахункової оцінки повітропроникності огороджувальних конструкцій». Усі будівлі енергетичного класу С, В або А та їх частини повинні бути спроектовані та збудовані так, щоб їх повітрообмін, виміряний згідно з ДСТУ Б В.2.219:2007. «Будинки і споруди. Метод визначення повітропроникності огороджувальних конструкцій в натурних умовах» при різниці тисків між внутрішньою та зовнішньою частиною 50Па не перевищував значень кратності повітрообміну, наведених у ДБН В 2.6-31. Для житлових, громадських, адміністративних, навчальних та медичних будівель це значення не повинно перевищувати 2,0 год-1.

Сутність методу полягає в тому, що через об'єкт, який випробовується, пропускають потік повітря і після встановлення 
стаціонарного потоку вимірюють витрати повітря та перепад тиску між об'ємом та зовнішнім середовищем чи між протилежними поверхнями конструкції. Випробування проводять при зниженні тиску та при підвищенні тиску відносно довкілля. За результатами вимірювань обчислюють узагальнені характеристики повітропроникності випробовуваного об'єкта або опір повітропроникності огороджувальної конструкції (приймається менше значення з двох отриманих результатів). [5]

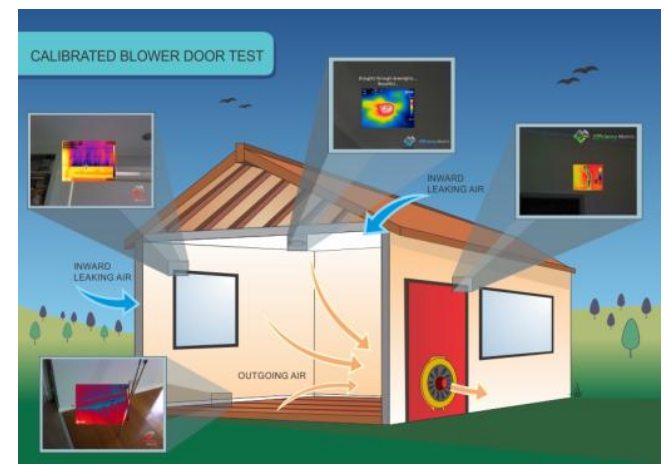

Рис. 3. Робота установки

Суть роботи установки полягає у створенні всередині будівлі розрідження або надлишкового тиску у 50 Па, що еквівалентно одночасному тиску вітру на огороджувальні конструкції зі швидкістю в межах 9-10 м/с.

Досягнути таких умов природним чином неможливо, тому дане обладнання $є$ незамінним при проведенні тепловізійного обстеження для виявлення місць інфільтрації та ексфільтрації повітря.

Для розуміння різниці між обстеженням з гарантованим перепадом тиску та без нього наведемо наступні термограми.
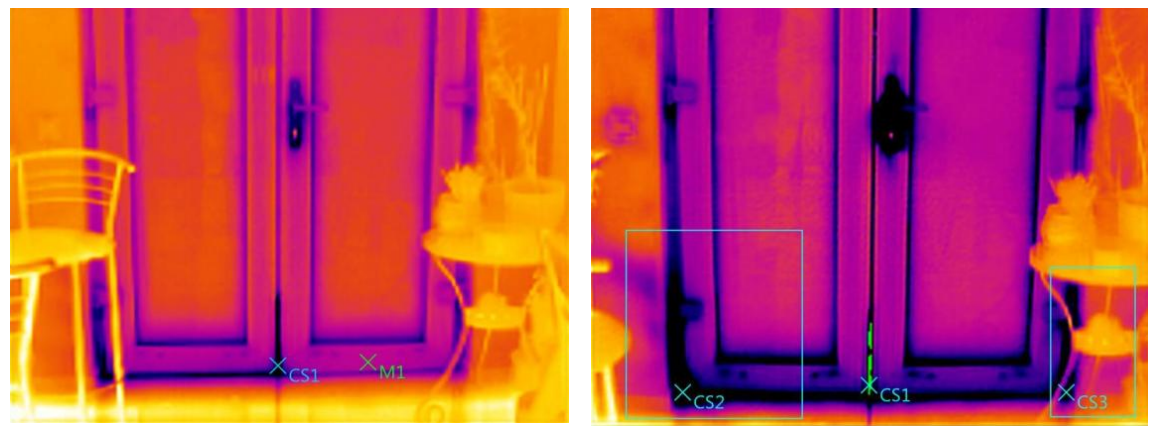

Рис. 4. Інфільтрація через вхідну групу 
"Сучасні технології та методи розрахунків у будівництві", випуск 12, 2019
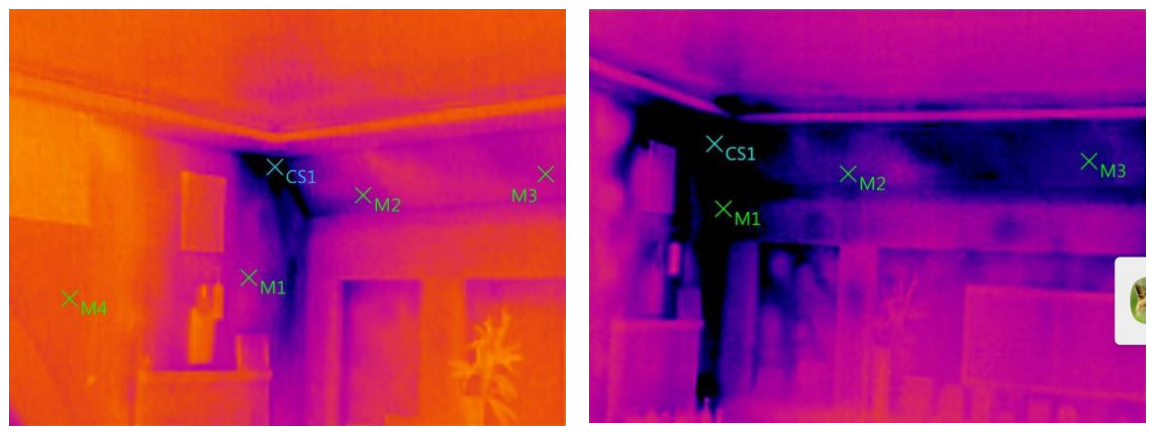

Рис. 5. Інфільтрація через стінове огородження
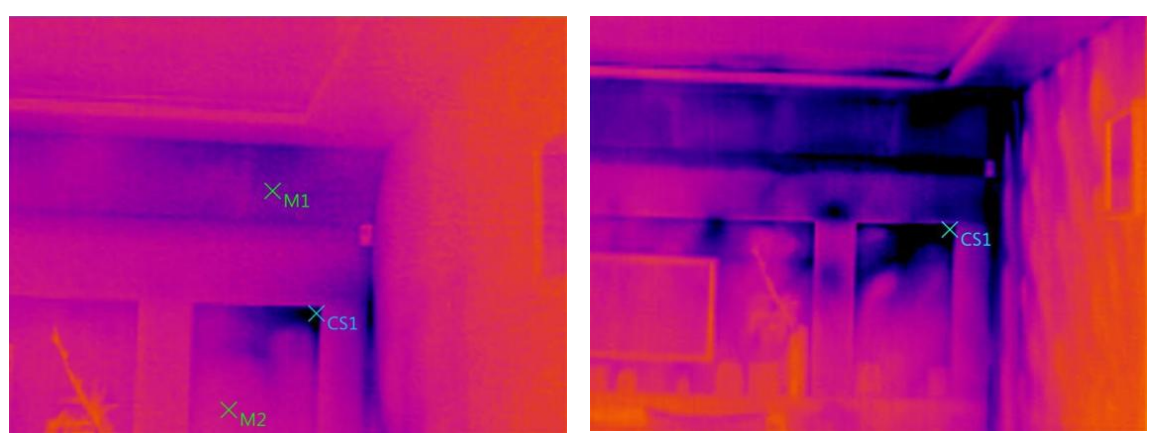

Рис. 6. Інфільтрація через стінове огородження
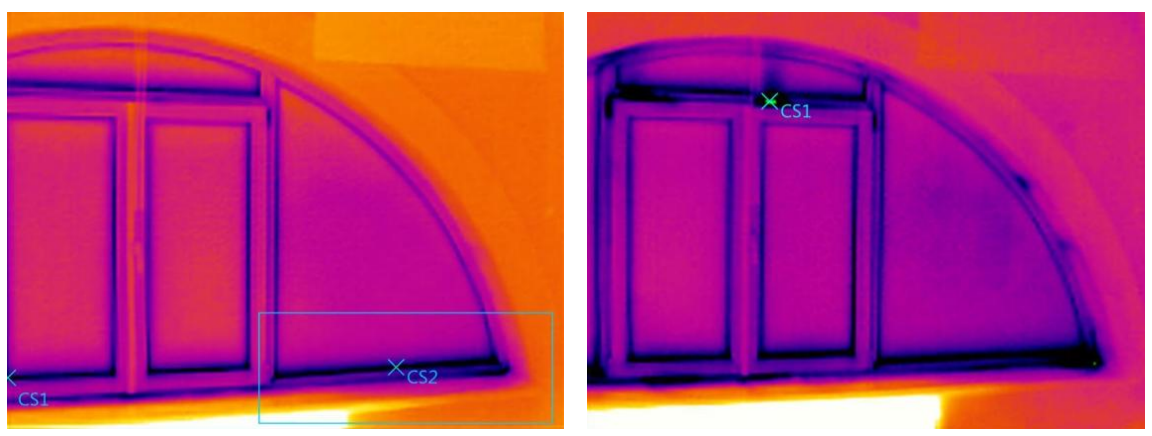

Рис. 7 Інфільтрація через примикання вікна та віконну конструкцію 

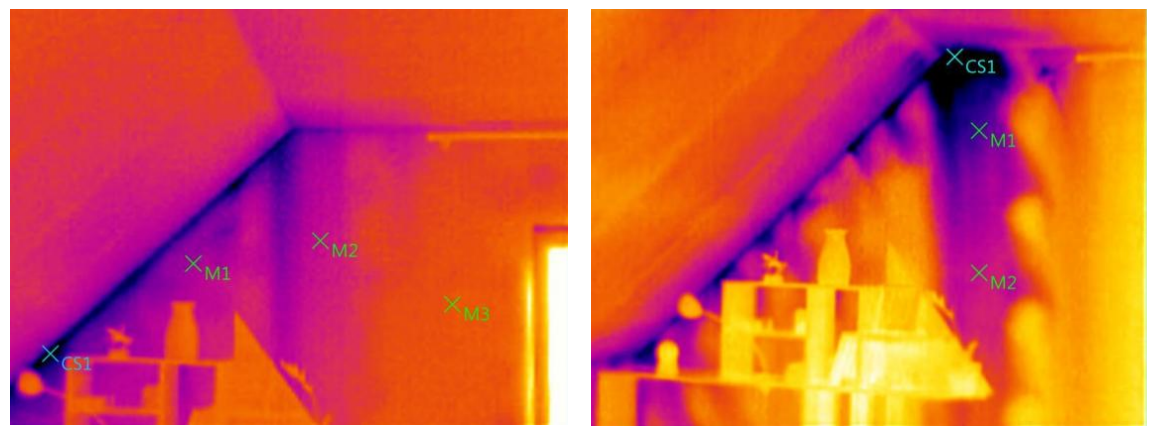

Рис. 8. Інфільтрація через стінове огородження

\section{Висновки}

- натурні дослідження та нормативна база говорять про необхідність різниці в тиску назовні і всередині будівлі;

- гарантовану різницю в тиску можна забезпечити лише спеціалізованим обладнанням;

- $\quad$ очевидною $є$ різниця у якості виявлення дефектів при додатковому створенні різниці в тиску і без нього.

\section{References}

1. DSTU B EN 13187:2011 Teplovi kharakterystyky budivel. Yakisne vyiavlennia teplovykh vidmov $\mathrm{v}$ ohorodzhuvalnykh konstruktsiiakh. Infrachervonyi metod (EN 13187:1998, IDT).

2. DBN V 2.6-31-2016 Teplova izoliatsiia budivel.

3. DSTU B V.2.2-19:2007. Budynky i sporudy. Metod vyznachennia povitropronyknosti ohorodzhuvalnykh konstruktsii v naturnykh umovakh.

4. DSTU-N B V.2.6-191:2013. Nastanova z rozrakhunkovoi otsinky povitropronyknosti ohorodzhuvalnykh konstruktsii.

5. DSTU B V.2.2-19:2007. Budynky i sporudy. Metod vyznachennia povitropronyknosti ohorodzhuvalnykh konstruktsii v naturnykh umovakh.

\section{Список використаної літератури}

1. ДСТУ Б ЕN 13187:2011 Теплові характеристики будівель. Якісне виявлення теплових відмов в огороджувальних конструкціях. Інфрачервоний метод (EN 13187:1998, IDT).

2. ДБН В 2.6-31-2016 Теплова ізоляція будівель.

3. ДСТУ Б В.2.2-19:2007. Будинки i споруди. Метод визначення повітропроникності огороджувальних конструкцій в натурних умовах.

4. ДСТУ-Н Б В.2.6-191:2013. Настанова 3 розрахункової оцінки повітропроникності огороджувальних конструкцій.

5. ДСТУ Б В.2.2-19:2007. Будинки і споруди. Метод визначення повітропроникності огороджувальних конструкцій в натурних умовах. 